\title{
Foraminiferal stratigraphy and palaeoecological implications in turbidite-like deposits from the Early Tortonian (Late Miocene) of Greece
}

\author{
H. DRINIA, A. ANTONARAKOU, N. TSAPARAS \& M. D. DERMITZAKIS \\ Department of Historical Geology and Palaeontology, Faculty of Geology and Geoenvironment, National and Kapodistrian University of \\ Athens, Panepistimiopolis, 157 84, Athens, Greece (e-mail: cntrinia@geol.uoa.gr)
}

\begin{abstract}
The Lower Tortonian Ag. Giannis section, in Gavdos Island, Greece, consists of an outer neritic to upper bathyal, marly hemipelagic sequence which is interrupted by thick turbidite-like sandy deposits. During deposition of the marly intervals, reworking was considerably reduced.

This paper contributes to knowledge concerning benthic foraminiferal response to dynamic sedimentary environments. Important palaeoecological information for benthic foraminiferal assemblages was gathered and analyzed in order to create a regionally consistent picture of the palaeoenvironment. Samples were analyzed statistically in order to identify the different palaeoenvironmental settings during turbiditic sedimentation. Undisturbed basal marls of the section are characterized by the predominance of a diversified Uvigerina striatissima assemblage typified by a broad variety of morphotypes with different inferred habitat preferences and feeding strategies, indicating rather well-oxygenated bottom waters. This environmental stability was subsequently disrupted by recurrent deposition of turbidite-like sands. A low-diversity Valvulineria complanata-Globobulimina sp. assemblage is dominant in this part of the succession, as these specialized endobenthic species could keep pace with high-energy sedimentary settings. Just above the turbidites, a "recolonization" fauna (Bolivina alata assemblage), composed entirely of infaunal elements is observed, indicating a nutrient-rich substrate. This oligotypic fauna is later replaced by a more diversified microfauna capable of occupying a wider range of ecological niches. J. Micropalaeontol. 26(2): 145-158, October 2007.
\end{abstract}

KEYWORDS: benthic foraminifera, turbidites, recolonization, Early Tortonian, eastern Mediterranean

\section{INTRODUCTION}

Gavdos Island (Fig. 1) forms the southernmost exposed part of the Hellenic Arc. Together with Crete, it is located between a volcanic arc to the north and a northward subduction zone (the Hellenic Trench) to the south. The Hellenic Arc and the Hellenic
Trench are associated with the northward subduction of the oceanic lithosphere of the African plate under the Aegean continental plate (e.g. McKenzie, 1978; Angelier et al., 1982). Subduction probably started in the Late Oligocene/Early Miocene (cf. Meulenkamp et al., 1988) and is ongoing.

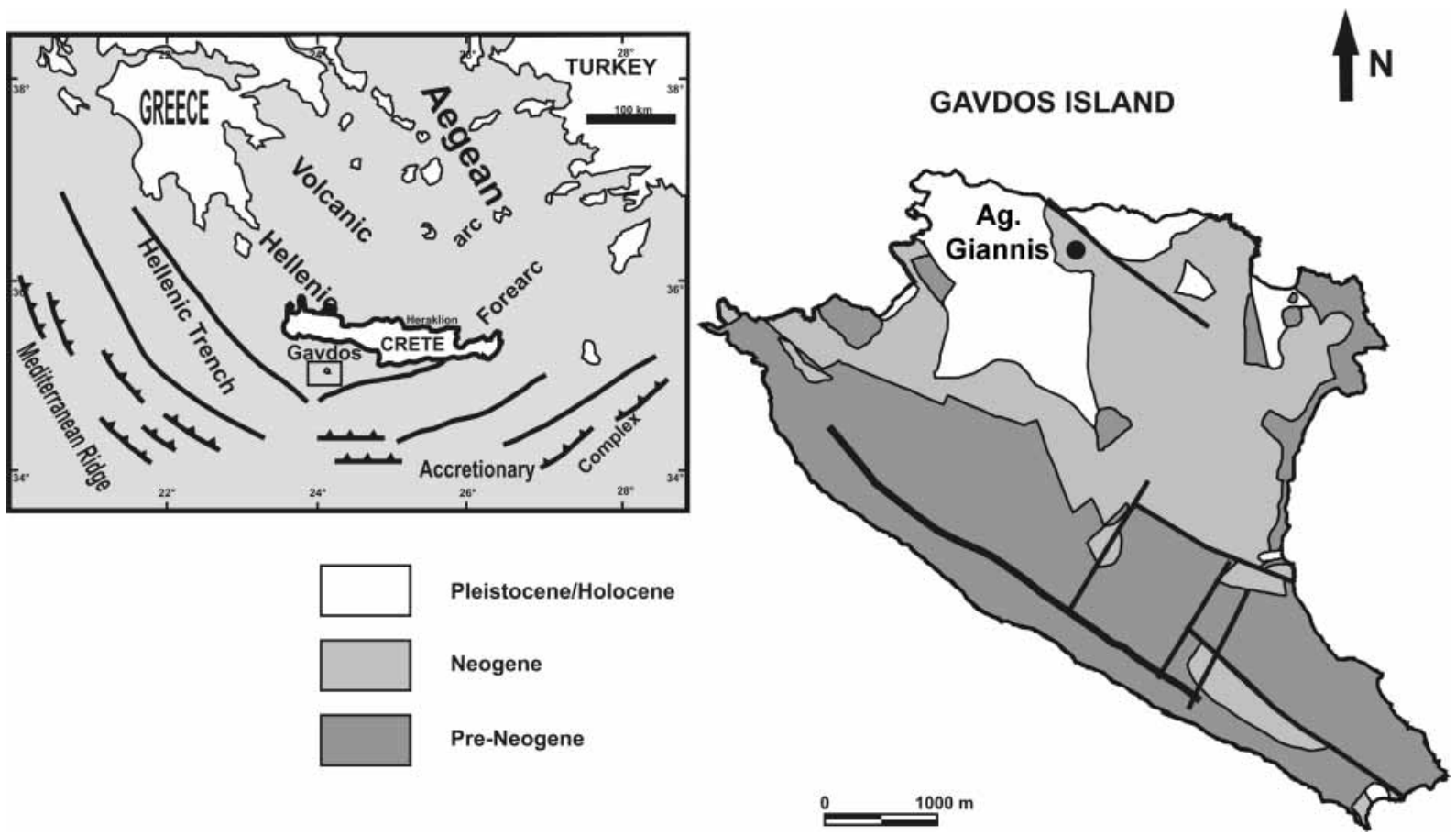

Fig. 1. Simplified geological map of Gavdos Island indicating the location of the study area (Ag. Giannis section). 
Therefore, the Neogene basins on Crete and Gavdos are part of an outer-arc setting. During the Tortonian, marked changes along the southern margin caused the Cretan area to be connected for the first time to the open sea (Fortuin, 1977, 1978). At that time, Crete and Gavdos became separated by an extensional basin (Peters \& Troelstra, 1984).

The pre-Neogene basement of the island of Gavdos consists of a Maastrichtian-Danian calcareous sequence topped by Eocene flysch (Vicente, 1970) belonging to the Pindos-Ethia geotectonic zone. Towards the northeastern part of the island, a Mesozoic volcano-sedimentary series is exposed and is thrust above the Pindos-Ethia sequence (Vicente, 1970; Seidel \& Okrusch, 1978). Neogene sediments have a maximum thickness of $150 \mathrm{~m}$ and cover about one half of the surface area of the island, unconformably overlying the Mesozoic substrate basement.

The island was probably affected by drastic subsidence during the Serravallian as documented by the changes in planktonic foraminifera, calcareous nannoplankton and molluscs (Anastasakis et al., 1995). According to these authors, the Neogene sediments of Gavdos Island can be subdivided into two lithostratigraphical formations: the Potamos and the Metochia formations.

The Potamos Formation (Late Serravallian-earliest Tortonian) is encountered along an elongate northwestsoutheast-trending trough occupying the middle part of the island. An angular unconformity, marked by a pronounced erosional surface, denotes the initiation of deposition of the Neogene sediments. At the base of the unconformity, a basal conglomerate is developed with pebbles derived from the Alpine units exposed on the island. Above this conglomerate, a coral limestone is usually present, overlain by a fossiliferous sandstone displaying alternations of grey-whitish bluish beds rich in shallow-marine molluscs, corals and Heterostegina larger foraminifera, as well as pebbles derived from the Alpine units.

The Metochia Formation occupies most of the northeast quarter of Gavdos Island. These sediments are found to overlay either the Alpine basement rocks or the Potamos Formation. They mostly comprise rhythmic alternations of poorly to nonbioturbated brown-grey sapropelic and bioturbated white-grey marly beds which show conspicuous clustering. The origin of this rhythmic layering has been related to orbital-forced variations in climate (Hilgen, 1991; Hilgen et al., 1995; Krijgsman et al., 1995). Its type-section spans the interval from 9.7 Ma to 6.6 Ma (Hilgen et al., 1995; Krijgsman et al., 1995). The sapropel-bearing succession is overlain conformably by cyclically bedded diatomites of Messinian age (Krijgsman et al., 1998; Triantaphyllou et al., 1999; Kouwenhoven et al., 2003; Drinia et al., 2004a).

Despite the extensive high resolution biostratigraphic studies and palaeoenvironmental reconstructions carried out in the Metochia Section, the older Potamos Formation of the island remains comparatively unexplored (e.g. Anastasakis et al., 1995; Drinia et al., 2004b).

The Ag. Giannis section is located in the northwestern part of Gavdos Island and is comprised of the Potamos Formation. The $77 \mathrm{~m}$ thick section consists of monotonous white to grey-blue marls, with abundant and generally well-preserved microfossils, and thick, turbidite-like sands.

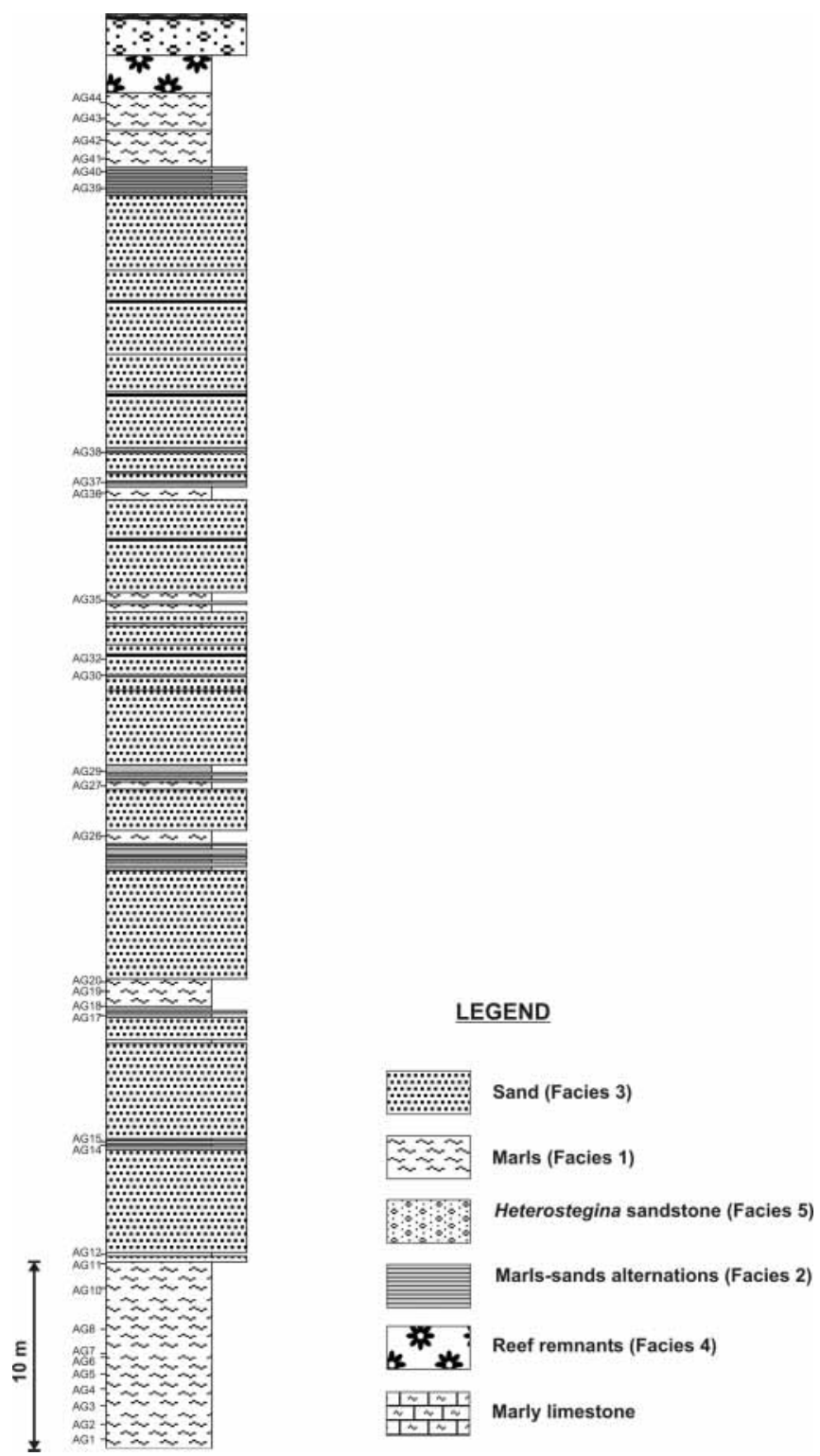

Fig. 2. Stratigraphical column of the Ag. Giannis section indicating sampling and Facies 1-5.

The purpose of the present research is threefold: (1) to trace the distribution of benthic foraminiferal assemblages in the turbiditic succession of the Ag. Giannis section; (2) to relate the faunal assemblages to environmental factors and to lithology; and (3) to reconstruct the palaeoenvironmental setting.

Important palaeoenvironmental information can be obtained through analyses of the fossil assemblages just before, during and after the turbiditic deposition.

\section{MATERIAL AND METHODS}

\section{Description of the studied section}

The Ag. Giannis section ( $77 \mathrm{~m}$ thick) has been divided into five sedimentary facies (Fig. 2), each one identified by 
lithology, physical and biological sedimentary structures and grain size.

Facies 1. Dominates the basal part of the studied section and comprises bluish, fossiliferous marls with occasional lenses or layers of fine- to very fine-grained sands. The marls are generally massive but, in places, thin laminations are visible.

Facies 2. Consists of thin-bedded and very fine- to fine-grained sands embedded in marls. All these sandy beds show a sharp base and fine upwards into marly layers. The thinly interbedded sands-marls facies resemble distal storm sands deposited below storm wave base (Rosenthal \& Walker, 1987; Pirrie, 1989) or, alternatively, fine-grained turbidites (Stow \& Piper, 1984) interbedded with marls deposited under lower-energy conditions.

Facies 3. Characterized by fine- to medium-grained, poorly sorted sands, which are laterally persistent. Generally, the base and the top of each sandstone bed are sharp and smooth surfaces. These beds are intercalated with thin marly horizons or very thin alternations of mudstone and very fine-grained sandstones. The rarity of sedimentary structures probably reflects the high rate of deposition.

Facies 4. In the upper part of the succession, there are relicts of a fractured reef with abundant corals, Chlamys latissima, Ostrea lamellosa, O. plicatula and gastropods. The presence of Porites, which is the main reef-builder in this part of the Ag. Giannis basin, indicates tolerance to salinity changes (Esteban, 1979). The presence of oysters indicates a nearshore shallow-water, reef environment with clear water and low turbidity (Korringa, 1952; Wells, 1961).

Facies 5. The uppermost levels consist of medium-sized partially cemented sandstone with no visible stratification. Bivalves, bryozoans, echinoids (Clypeaster) and larger foraminifera (Heterostegina) dominate, with minor proportions of gastropods. The biogenic content of this facies implies a fully marine shelf setting. The biota is well preserved, indicating a rather calm depositional setting below wave abrasion depth (WAD), (Brachert et al., 2003). The presence of Heterostegina indicates a depositional environment in the lower part of the photic zone (e.g. James et al., 2001), characterized by warm-temperate surface temperatures (Betzler et al., 1997).

Based on the facies description above, the sediments of the Ag. Giannis section are characterized by the presence of turbiditelike sediments interbedded into hemipelagic marls. However, they differ from typical turbidites by the absence of graded bedding, moderate sorting and well-developed primary sedimentary structures, as described by Bouma et al. (1985).

Moreover, the lack of evidence for significant slumped beds indicates the presence of a very low palaeo-gradient. This gentle gradient immediately excludes slope- and base-of-slope fans, which have gradients of $1-10^{\circ}$ (Stow, 1986), whereas the average gradient of modern shelves is only $0.1^{\circ}$ (Shepard, 1963). Hence, facies associations are consistent with a shelf environment. The turbidite-like deposits in this shallow-water setting are likely to have been triggered by stream floods during periods of extreme discharges rather than by slope instability (cf. Balance, 1988; Colmenero et al., 1988; Dabrio \& Polo, 1988; Marzo \& Anadon, 1988).

\section{Micropalaeontological analyses}

Quantitative analysis of benthic foraminifera has been carried out in order to document changes in assemblages throughout the Ag. Giannis section.

Samples analysed were collected from Facies 1 and from the marly intervals of Facies 2. Sands (Facies 3) above and below the marly intervals were generally not sampled but, when studied, yielded poorly preserved microfossils.

Forty-four samples were washed and dried (Fig. 2). After drying, they were wet-sieved through a $125 \mu \mathrm{m}$ mesh sieve. Of the 44 samples analysed, only 32 proved to be suitable for quantitative analysis. In the remaining samples, foraminifera are present but in very low, insignificant numbers. Two fractions from each sample were taken to carry out an analysis of benthic and planktonic foraminifera.

Planktonic foraminifera were studied for age determination, using a quantitative approach; all representative specimens were picked from the split, identified at specific level and mounted on microslides for a permanent record. Raw data were transformed into percentages over the total abundance of planktonic foraminifera (Fig. 3). Finally, the remaining sample was scanned for rare species.

All benthic foraminifera were picked from the split, identified and counted. Planktonic forms were also counted and the percentage of planktonics $(\% \mathrm{P})$ was computed.

Raw data of benthic foraminifera were then transformed into percentages over the total abundance, and percentage abundance curves were plotted (Fig. 5). Taxonomic concepts were based on Wright (1978), Blanc-Vernet et al. (1979), AGIP (1982), Bizon \& Bizon (1984), Venec-Peyre (1984), Jorissen (1988), Cimerman \& Langer (1991) and Van de Poel (1992). The generic attribution follows Loeblich \& Tappan (1988).

For each sample, the Fisher- $\alpha$ index, the dominance and the percentages of epifaunal-shallow infaunal and deep infaunal forms were calculated (Fig. 6). The identification of epifaunal vs. infaunal groups (Fig. 9) was carried out using the morphogroup classification of Murray (1991), Barmawidjaja et al. (1992), Jorissen et al. (1992), Jorissen (1999) and Jorissen \& Wittling (1999). The inferred mode of life for each taxon is reported in Appendix A.

In order to estimate the changes in palaeobathymetry during the deposition of the Ag. Giannis section, the percentage of planktonic foraminifera $[\% P /(P+B)]$ was calculated, where $P$ is the number of specimens of planktonic foraminifera and $B$ is the number of specimens of benthic foraminifera (Fig. 11), and each assemblage was compared with other Late Miocene and Recent assemblages from the available literature.

Dysoxic, oxic and suboxic environments were identified (Fig. 10) using the Benthic Foraminifera Oxygen index (BFOI) of Kaiho (1991, 1994), following the limitations expressed in Baas et al. (1998) and Stefanelli (2004); this index appears to be designed more for modern open-oceanic faunas than for shallow Mediterranean faunas.

Multivariate analyses were performed on benthic foraminiferal species relative abundance data for palaeoenvironmental reconstructions. For this purpose, some species, represented by small numbers in the fauna, were lumped together (e.g. Lenticulina spp., Lagena spp., Nodosaria spp., Miliolidae, Agglutinants). 


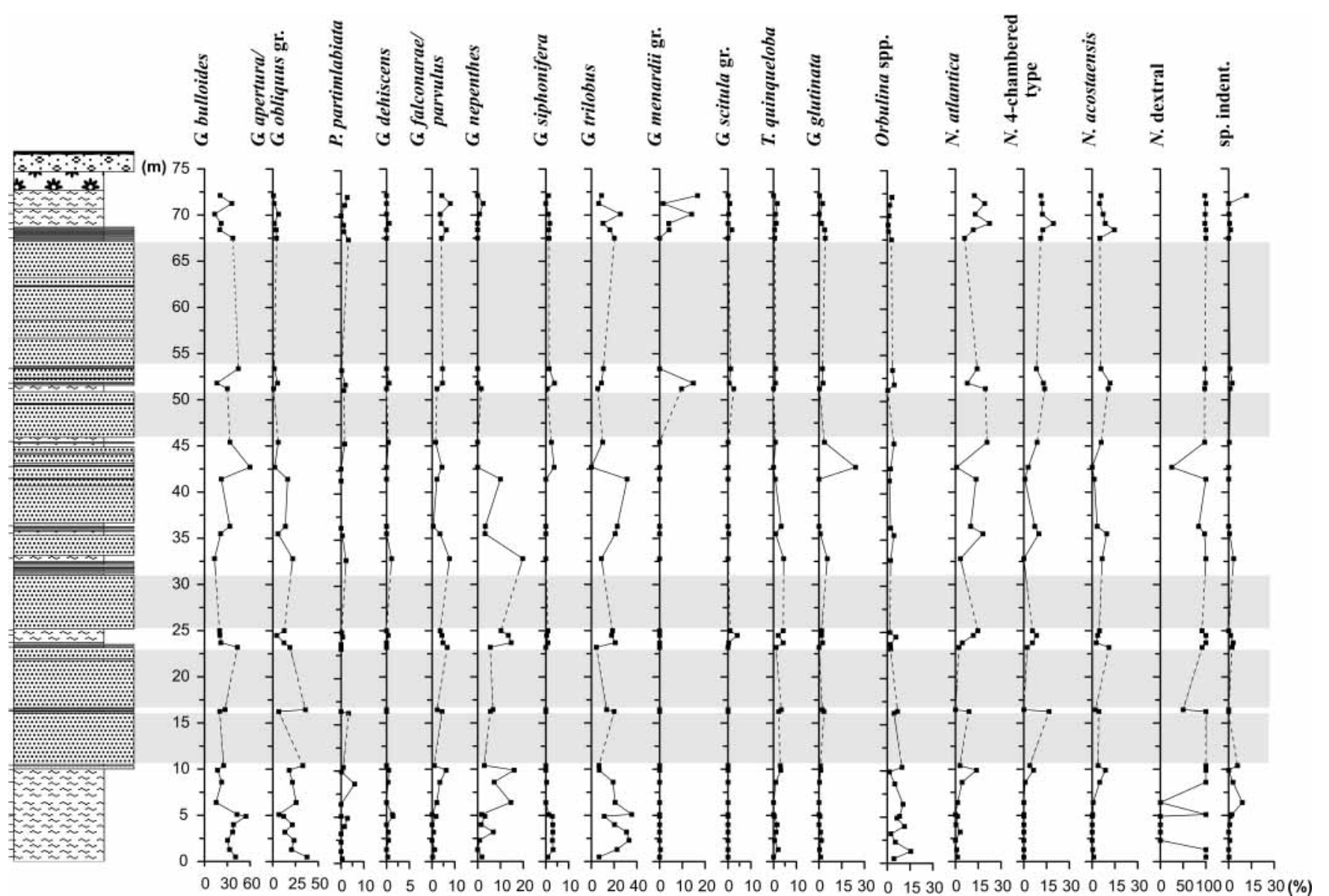

Fig. 3. Relative frequency data for the selected planktonic foraminifera from the Ag. Giannis section. Dashed lines indicate the presence of thick turbidite beds (no data). See Figure 2 for legend.

Q-mode cluster analysis was performed using Ward's Minimum Variance method (Ward, 1963). A program developed by Hammer et al. (2001) generated the dendrogram (Fig. 7). Census data are based on the occurrence of abundant species. Rare taxa $(<2 \%$ relative abundance) were omitted in the calculation as they were considered to be statistically insignificant (Kovach, 1987, 1989). Consequently, the 174 benthic foraminiferal species identified were reduced to the 37 species and groups of species considered to be the most significant.

Finally, a standardized principal component analysis (PCA; R-mode) was also performed in order to trace the palaeoecological significance of each assemblage (Fig. 8).

\section{RESULTS}

\section{Biostratigraphy}

Distribution patterns of the most representative planktonic foraminiferal taxa are summarized in Figure 3. Preservation is generally good in the bluish marls and fairly poorer in the thin marly layers that are intercalated in the sands. The 22 identified planktonic foraminiferal species were lumped into 16 categories: Globigerina bulloides group, Globigerinoides obliquus/ Globoturborotalita apertura, Paragloborotalia partimlabiata, Globoquadrina dehiscens, Globorotaloides falconarae,
Globoturborotalita nepenthes, Globigerinella siphonifera, Globigerinoides trilobus, Globorotalia menardii, G. scitula group, Turborotalita quinqueloba, Globigerinita glutinata, Orbulina spp., Neogloboquadrina atlantica, $N$. acostaensis s.s. and fourchambered Neogloboquadrinids.

The Globigerina bulloides group includes the species $G$. bulloides and $G$. falconensis. The species Globoturborotalita apertura and Globigerinoides obliquus were counted together because the poor preservation often obscured the supplementary opening. This group also includes the species Globoturborotalita decoraperta which was identified in some samples. The Globorotalia scitula group comprises all the unkeeled globorotaliids. Paragloborotalia partimlabiata was counted and plotted separately for biostratigraphy.

Orbulina spp. comprises the species $O$. universa, $O$. suturalis and $O$. bilobata. The Globigerinoides trilobus group includes the G. sacculifer type and G. trilobus.

Specimens identified as Globorotaloides falconarae include the types described previously as Catapsydrax parvulus (Zachariasse, 1992; Krijgsman et al., 1995, 1999). In the Mediterranean, the small-size type of $G$. falconarae cannot be distinguished from $C$. parvulus (Foresi et al., 2002a).

Species having biostratigraphical significance in our record are the neogloboquadrinids and the occurrence of 


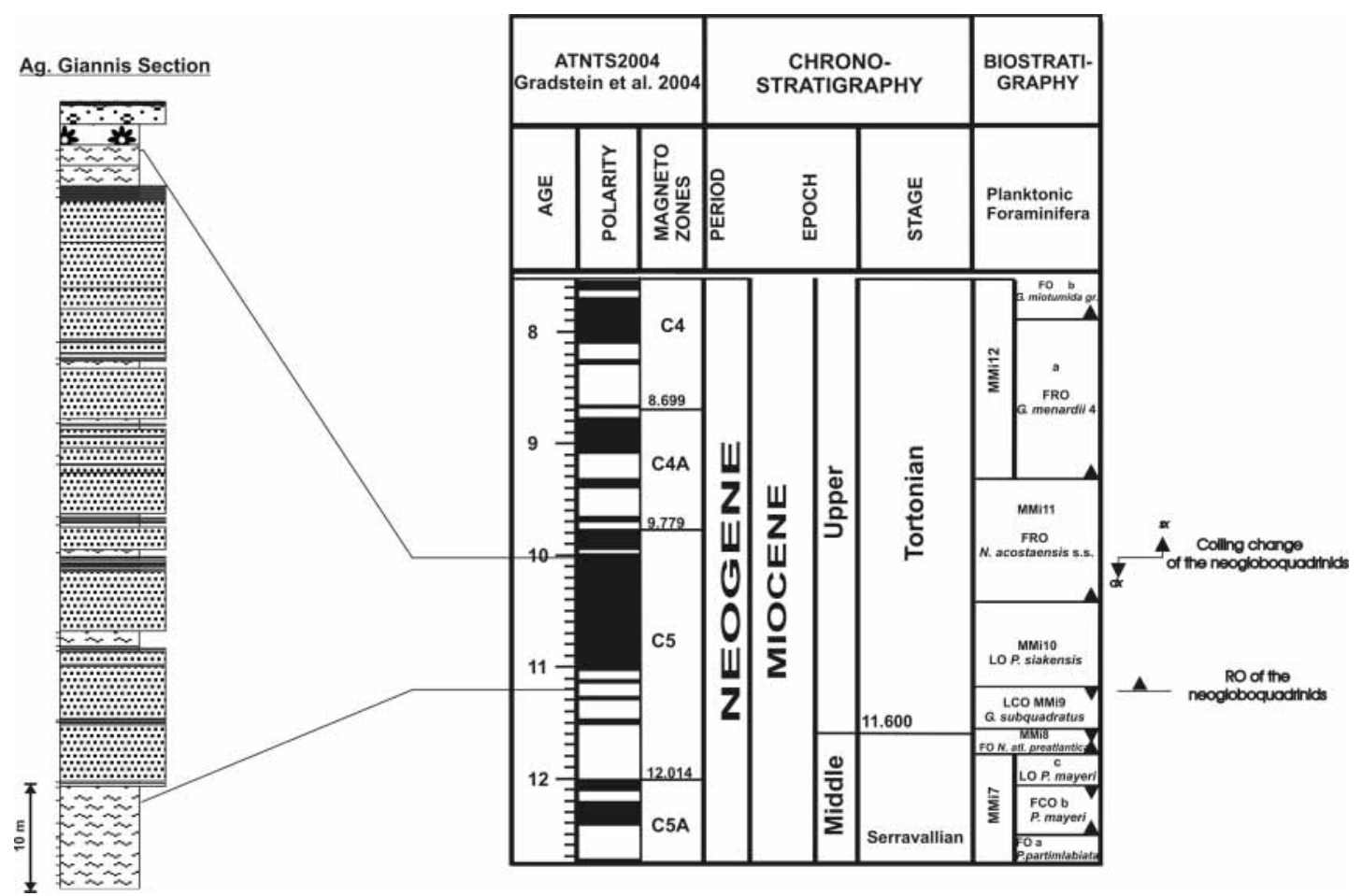

Fig. 4. Chronostratigraphic framework of the studied section (ages based on Gradstein et al., 2004). See Figure 2 for legend.

Paragloborotalia partimlabiata (Fig. 4). The last species, although present, is rare throughout. According to Hilgen et al. (2000), P. partimlabiata occurs up to $9.91 \mathrm{Ma}$ (absolute ages derived from Gradstein et al., 2004).

Specimens identified as Globigerinoides subquadratus occur very rarely $(<2 \%)$, in particular in the basal $3 \mathrm{~m}$ of the section and for that reason it was not plotted. The last common occurrence (LCO) of G. subquadratus has been dated in the Mediterranean at $11.54 \mathrm{Ma}$. This event slightly postdates the first regular occurrence (FRO) of Globigerinoides obliquus $(11.478 \mathrm{Ma})$ and is close to the end of the first influx of the neogloboquadrinids (Hilgen et al., 2000, 2003; Foresi et al., 2002a). Globigerinoides obliquus is present in all the samples, from the base of the studied section.

Neogloboquadrinids are the main constituents in the record. Within this group three types are distinguished: $N$. atlantica, $N$. acostaensis s.s. and the so-called Neogloboquadrina fourchambered type of Hilgen et al. (2000), as it was observed in the Monte Gibliscemi section (Hilgen et al., 2000) and in Monte dei Corvi (Hilgen et al., 2003). Specimens of N. acostaensis are typical, as described by Blow (1969). The $N$. four-chambered types follow the taxonomic concept of Hilgen et al. (2000). Such specimens have a medium to low-arched extra-umbilical aperture with or without lip and four chambers in the final whorl.

Specimens identified as $N$. atlantica are characterized by their generally small-sized tests, four chambers in the final whorl, with the last chamber slightly depressed. They have an arched umbilical-extraumbilical aperture bordered by a thick lip. This definition follows that of Foresi et al. (2002b) for $N$. atlantica praeantlantica, whereas Hilgen et al. (2000) described these forms as $N$. atlantica small-size. In the current record, $N$. atlantica atlantica (Foresi et al., 2002b) was not identified, as the wall structure was not recognized easily and bigger sized tests were not present.

Neogloboquadrina atlantica praeatlantica first occurs at $11.78 \mathrm{Ma}$ astronomical age of Hilgen et al. (2000) and Foresi et al. (2002a) and vanishes within the Globigerinoides extremus Zone of Foresi et al. (1998). According to Hilgen et al. (2000), its LRO is recorded around $10.48 \mathrm{Ma}$. In the Mediterranean, the first occurrence of the neogloboquadrinids is also recorded at 11.78 Ma. Within the distribution pattern of the neogloboquadrinids, Foresi et al. (2002a) and Hilgen et al. (2000) recognized a paracme interval which includes only rare and scattered occurrences of the Neogloboquadrina types. This interval is recorded from 11.54 Ma to 11.21 Ma, and ends just after the last occurrence of Paragloborotalia siakensis. Above this level, Neogloboquadrina species have a continuous distribution.

In the Ag. Giannis section, the neogloboquadrinids are continuously present from $10 \mathrm{~m}$ of the section upward. According to Foresi et al. (2002a), it was assumed that this level corresponds to the second influx of neogloboquadrinids with an astronomical age of $11.21 \mathrm{Ma}$. The absence of $P$. siakensis supports this interpretation.

Coiling changes in this species have been proven to have potential biostratigraphical significance, being random between $11.781 \mathrm{Ma}$ and $11.546 \mathrm{Ma}$ and persistently right $(>80 \%)$ between $11.178 \mathrm{Ma}$ and 10.011 Ma. According to the percentage curve, dextral neogloboquadrinids seem to prevail in all the samples.

Within the studied time span, the regular occurrence of $G$. obliquus, the absence of $G$. subquadratus, the absence of $P$. siakensis (LO 11.205 Ma, Hilgen et al., 2000; 11.21 Ma, Foresi et al., 2002a) and the regular distribution of Neogloboquadrina group, dextral coiling were observed. 


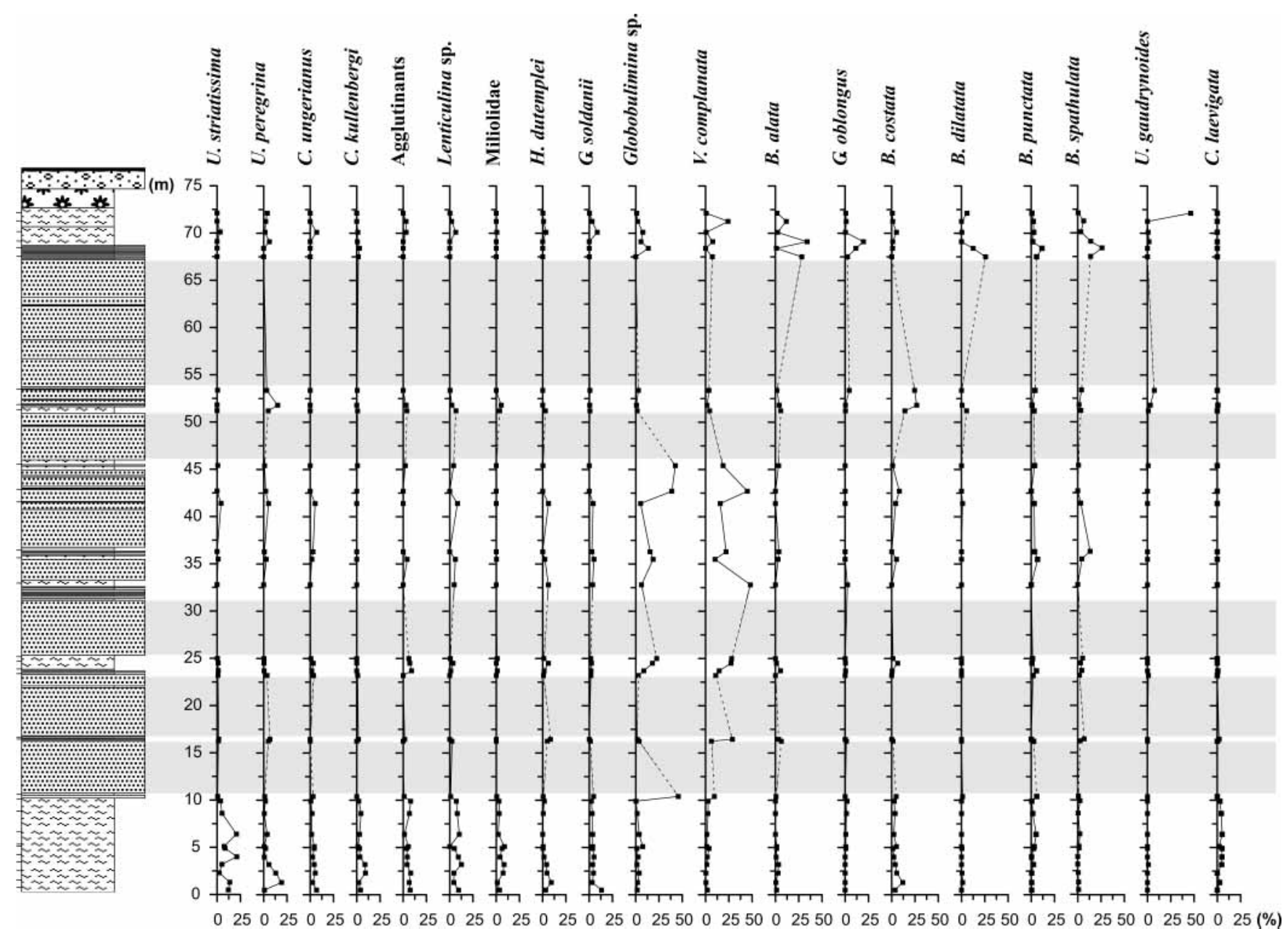

Fig. 5. Relative frequency data for the selected benthic foraminifera from the Ag. Giannis section. Dashed lines indicate the presence of thick turbidite beds (no data). See Figure 2 for legend.

Consequently, the sediments of the Ag. Giannis section were deposited between the age of the second influx of Neogloboquadrina species $(11.21 \mathrm{Ma})$, as defined in the astronomical tuned sections of Tremiti Island and Monte Gibliscemi, and the shift in coiling direction of $N$. acostaensis at $10.011 \mathrm{Ma}$ (Fig. 4).

\section{Benthic foraminiferal trends}

Figure 5 displays the stratigraphic distributional pattern of the most common and ecologically significant species and groups of species.

Among the uvigerinids, Uvigerina peregrina is common throughout the succession, with average percentage values fluctuating in the range of $1-20 \%$ and an abundance peak at $1.3 \mathrm{~m}$. $U$. striatissima shows two maxima, at $4 \mathrm{~m}$ and $5.1 \mathrm{~m}$, but it is rare in the rest of the succession. U. gaudrynoides, which is absent in the basal part of the section, first appears at $45.4 \mathrm{~m}$, reaching an abundance peak of $46.34 \%$ in the uppermost part of the record, at $72.12 \mathrm{~m}$.

Bolivina punctata and B. spathulata are common from the base up to the top of the succession, with a peak at $68.4 \mathrm{~m}(12 \%$ and $26 \%$, respectively). B. alata is generally rare and increases in abundance from $67.5 \mathrm{~m}$ up to the top of the section, showing its highest occurrence at $69.1 \mathrm{~m}(34.02 \%)$. A similar trend in abundance has been observed for $B$. dilatata, which appears at $51.2 \mathrm{~m}$ and shows its highest percentage value at $67.5 \mathrm{~m}$ (25.81\%). Bulimina costata is abundant in the $42-53.37 \mathrm{~m}$ interval, but is rare in the other intervals.

Among the epifaunal taxa, Cibicidoides kullenbergi and C. ungerianus are rare throughout the section. Their highest abundance values are in the lower $10 \mathrm{~m}$ of the record $(16.7 \%)$.

Finally, Globobulimina sp. and Valvulineria complanata, although well presented throughout the section, display highest occurrence in the middle part of the record, in the marly intervals of the turbidite-like deposits of Facies 2, from $25 \mathrm{~m}$ to $51.2 \mathrm{~m}$, with peak percentage values at $45.4 \mathrm{~m}(42.57 \%)$ and $32.8 \mathrm{~m}(48.15 \%)$, respectively.

At $16.25 \mathrm{~m}$ and $23.2 \mathrm{~m}$, above thick sandy levels, specimens of Ammonia beccarii and Elphidium spp. have been also recorded in significant abundance. These species are commonly found displaced to greater depths in Mediterranean sediments (e.g. Van der Zwaan, 1983; Jorissen, 1987). Consequently, they are considered to be allochthonous species.

Concerning the diversity indices of the studied record (Fig. 6), dominance ranges from $5 \%$ to about $50 \%$, with highest values at 


\section{Number of taxa \\ Dominance Fisher-alpha}

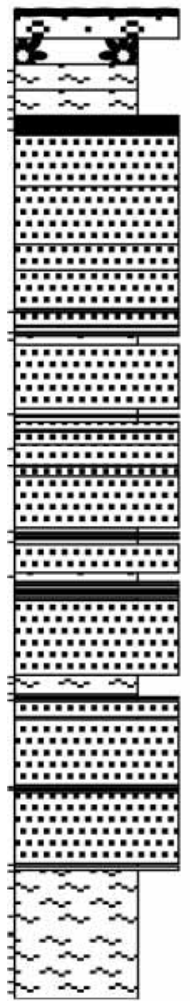

(m) 75

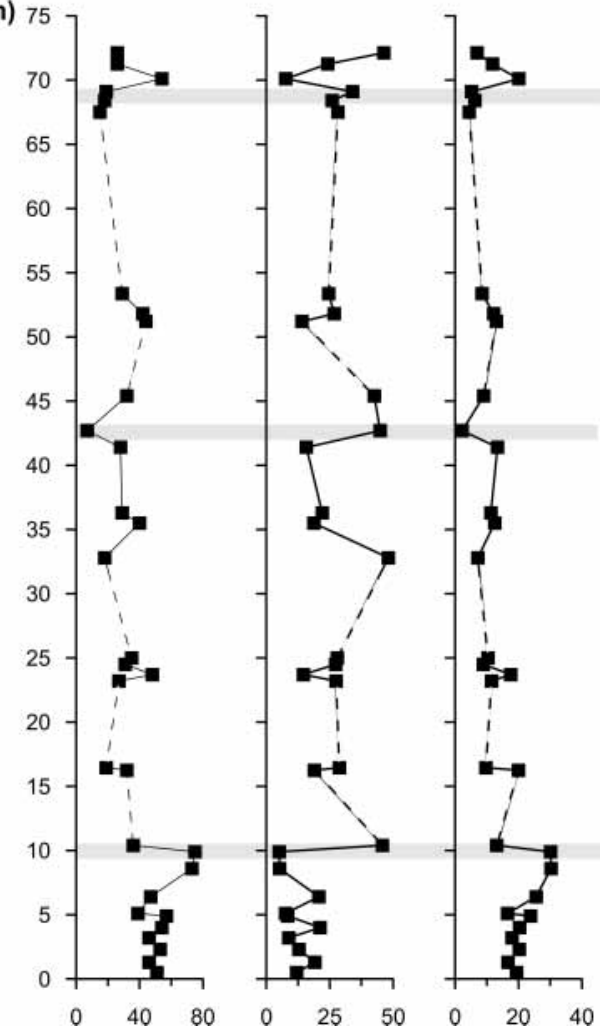

Fig. 6. Distribution patterns of the calculated diversity indices (number of taxa, dominance and Fisher-alpha). Note the considerable differences in diversity below, across and above the turbitic episodes. Dashed lines indicate the abrupt changes in diversity indices. See Figure 2 for legend.
$32.8 \mathrm{~m}$ (Facies 2), where $V$. complanata predominates. Intervals with high benthic diversity contain about 50-70 different taxa, with dominance ranging from $8 \%$ to $30 \%$. In low-diversity intervals, the number of taxa decreases to fewer than 20. The least number of species (7) was found at $42.7 \mathrm{~m}$ (Facies 2) and the maximum number (75) at $9.9 \mathrm{~m}$ (Facies 1) of the studied succession. The Fisher- $\alpha$ index shows its highest values at $9.9 \mathrm{~m}$ (30.13), suggesting a well-diversified fauna, and its lowest values (2.23) at $42.7 \mathrm{~m}$, indicating some deviation from the norm of the palaeoenvironmental parameters (Jorissen, 1987; Van der Zwaan \& Jorissen, 1991).

Q-mode clustering of the percentage contribution of 37 species to each of 32 samples clearly separates two major groups, each one corresponding to groups of samples containing similar benthic foraminiferal assemblages. The first group consists mainly of twelve samples, representing samples in between the turbiditic sands (Facies 2), whereas the second group includes all the remaining samples. A further subdivision of the second cluster enables one to distinguish seven samples, representing the stratigraphic interval above the turbiditic sands. The dendrogram (Fig. 7) groups the samples into clusters characterized by the dominance of certain species.

Cluster I ( $V$. complanata-Globobulimina spp. assemblage) covers the middle part of the succession and includes the samples recovered from the marly beds of Facies 2 (samples AG12-AG35 and AG43). According to Van der Zwaan (1982), these species are particularly frequent during periods of increased productivity. Moreover, they are not tolerant of increased salinities. In fact, Jorissen $(1987,1988)$ found benthic foraminiferal communities very similar to the assemblage of Cluster I in the pelitic belt created in the Adriatic Sea by the sediment supply of the Po River. In addition, Van der Zwaan \& Jorissen (1991) stressed the high impact of increased terrestrially

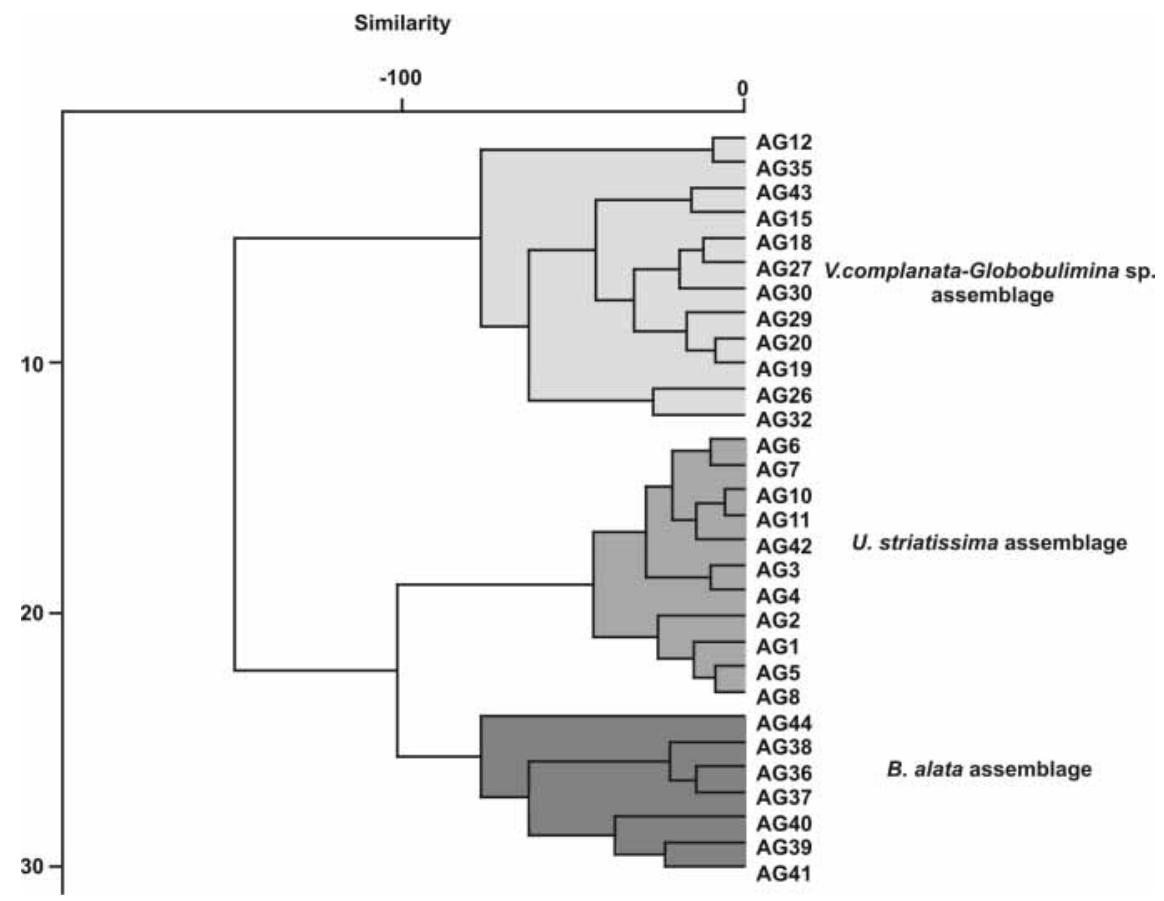

Fig. 7. Dendrogram classifications of the benthic foraminfera samples produced by Q-mode cluster analysis, indicating the three assemblages defined. 
derived nutrient, organic matter and sediment input on this kind of assemblage. A comparable association was found in Upper Miocene sediments of Potamidha on Crete (Wonders \& van der Zwaan, 1979), in the northern Italian Sant'Agata section and in the Scardilli section (Van der Zwaan \& den Hartog Jager, 1983). Therefore, the $V$. complanata-Globobulimina assemblage is interpreted to indicate an increased amount of $\mathrm{C}_{\text {org }}$ in the bottom sediments due to increased input of nutrients from the continent.

Cluster IIa ( $U$. striatissima assemblage) is recorded in the basal part of the section (Facies 1). It includes samples AG1AG11 and AG42, and is dominated by Uvigerina striatissima with rarer Cibicidoides spp. U. striatissima is reported as a species tolerant of only moderate oxygen deficiency (Borsetti et al., 1986; Bellanca et al., 2002). The contemporaneous presence of Cibicidoides spp., epifaunal taxa with planoconvex or biconvex trochospiral tests, is considered indicative of oxic environments (e.g. Corliss, 1991; Kaiho, 1994). Moreover, the joint percentages of Lenticulina species (Fig. 5) are highest in this part of the section and support the hypothesis of a higher oxygen content (e.g. Van Leewen, 1986; Corliss \& Emerson, 1990; Sjoerdsma \& van der Zwaan, 1992; Kaiho, 1994). Some elements of this assemblage are present in the Scardilli (Van der Zwaan \& den Hartog Jager, 1983) and Falconara sections (Van der Zwaan, 1982). They were regarded by Van der Zwaan (1982) as characteristic of stable, deep-marine conditions, not affected greatly by changes in salinity, oxygen content or nutrient amount.

Cluster IIb (B. alata assemblage) is recorded in the upper part of the section (Facies 1) and includes samples AG36-AG41 and AG44. This assemblage is characterized by a great number of individuals, belonging to the infaunal species $B$. alata, $B$. dilatata and $B$. spathulata, with Bulimina costata also present in significant abundances. In sample AG44 (uppermost part of the section) Uvigerina gaudrynoides - a species that displays high relative abundances in oxygen-deficient and presumably nutrient-rich environments (Van der Zwaan, 1982) - replaces $B$. alata and $B$. dilatatalspathulata, suggesting that the depositional environment became shallower. All these species are tolerant of low-oxygen conditions (Van der Zwaan, 1982; Jonkers, 1984; Katz \& Thunell, 1984; van der Zwaan \& Gudjonsson, 1986). A comparable association has also been observed in the Skardilli section in Sicily (Van der Zwaan \& den Hartog Jager, 1983), as well as in other Cretan sections.

The aforementioned qualitative interpretations of the assemblages are confirmed by the R-mode factor analysis, resulting in two principal axes accounting for $35.35 \%$ and $30.99 \%$ respectively. Loading scores for the first two axes are reported in Table 1. Based on PCA scores, three assemblages dominated by particular taxa were identified (Bolivina alata assemblage, $V$. complanata-Globobulimina spp. assemblage and Uvigerina striatissima assemblage). These display a distinctive distribution across the Ag. Giannis section (Fig. 8).

Figure 9 displays the distributional pattern of epifaunashallow infauna and deep infauna throughout the Ag. Giannis section. Below the turbiditic sands, the assemblages (Uvigerina striatissima assemblage) are characterized by a rather stable epifaunal/infaunal ratio, with an average relative abundance of infaunal forms around 35\%. The 'bloom' in the elongate morphotypes that dominate the Bolivina alata assemblage is reflected

\begin{tabular}{lrr}
\hline Species & Factor 1 & Factor 2 \\
\hline Bolivina alata & $\mathbf{0 . 9 4}$ & -0.11 \\
Bulimina spp. & -0.10 & -0.11 \\
Cancris auriculus & -0.01 & -0.02 \\
Cibicidoides kullenbergi & -0.01 & -0.05 \\
Cassidulina laevigata & -0.03 & -0.04 \\
Cibicides lobatulus & -0.01 & 0.01 \\
C. pseudoungerianus & -0.01 & 0.01 \\
C. ungerianus & -0.04 & -0.02 \\
Gyroidina altiformis & -0.01 & -0.01 \\
Gavelinopsis lobatulus & 0.00 & -0.02 \\
Gyroidinoides neosoldanii & -0.02 & -0.02 \\
Gyroidina soldanii & -0.03 & 0.00 \\
Globocassidulina oblonga & 0.13 & -0.03 \\
Globobulimina spp. & -0.02 & $\mathbf{0 . 5 3}$ \\
Hoeglundina elegans & -0.01 & -0.02 \\
Heterolepa sp. & -0.04 & 0.01 \\
Lagena sp. & -0.01 & 0.03 \\
Lenticulina spp. & -0.07 & -0.04 \\
Miliolidae & -0.04 & -0.06 \\
Nodosaria sp. & -0.02 & 0.01 \\
Oridorsalis umbonatus & -0.02 & 0.00 \\
Pullenia bulloides & -0.01 & 0.00 \\
Plectofrondicularia sp. & -0.01 & -0.02 \\
Siphonina reticulata & -0.02 & -0.02 \\
Stilostomella sp. & -0.01 & 0.02 \\
Uvigerina striatissima & -0.25 & $-\mathbf{0 . 5 3}$ \\
Valvulineria complanata & -0.05 & $\mathbf{0 . 6 3}$ \\
\hline & &
\end{tabular}

Table 1. Factor loadings for the benthic foraminiferal species from the Ag. Giannis section, imported into statistical analysis.

in a peak of infaunal forms, occurring just above the turbiditic sands, with a maximum value of $90 \%$.

Although based on few samples, a gradual recovery to average values comparable to that of the pre-turbiditic interval can be observed upsection.

\section{Oxygen content}

The benthic foraminiferal assemblages recovered from the Ag. Giannis section reveal Benthic Foraminifera Oxygen Index (BFOI) values ranging from -6 to 80 . Index values between -6 and 39 correspond to oxygen concentrations between $1.5 \mathrm{ml}^{-1}$ and $3 \mathrm{ml} \mathrm{1}^{-1}$, values $>39$ correspond to $>3 \mathrm{ml} \mathrm{l}^{-1}$ oxygen content (Kaiho, 1994).

Figure 10 shows that the entire section is characterized by high abundance of the dysoxic and suboxic taxa while the oxic indicators are of minor importance. The abundances of oxic indicators decline slightly, while suboxic and dysoxic increase upsection. On the basis of this pattern, three intervals are distinguished:

Interval I (from 0 to $9.9 \mathrm{~m}$ ) is characterized by higher oxic conditions. The assemblage of this interval records BFOI values between 33 to 80 indicating a high/medium oxic regime. Interval II $(9.9-53.37 \mathrm{~m})$ is characterized by a decline in abundance of the oxic indicators and an increase in the suboxicdysoxic morphogroups. BFOI values range from 12.5 to 36 , suggesting a low oxic regime.

Interval III (53.37-72.12 $\mathrm{m})$ is characterized by the presence of potentially infaunal taxa, suggesting that a suboxic period occurs. The BFOI values range from -6 to 4 due to the high ratios of suboxic indicators, while the oxic indicators are 

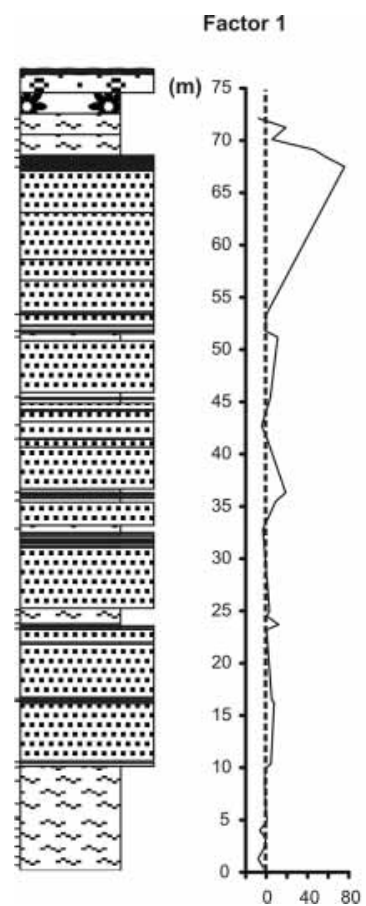

Factor 2

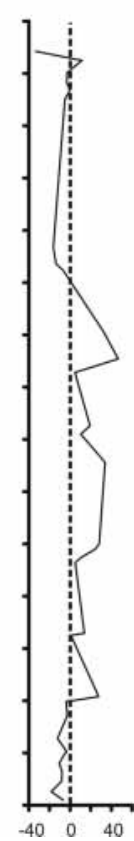

Fig. 8. Vertical distribution of the benthic foraminifera factor scores extracted by R-mode factor analysis which allowed the 27 species and species groups to be classified into three assemblages. Factor 1 shows positive factor loadings for the $B$. alata assemblage. In factor 2, positive loadings are for the $V$. complanata-Globobulimina spp. assemblage, whereas negative loadings are for the $U$. striatissima assemblage. See Figure 2 for legend.

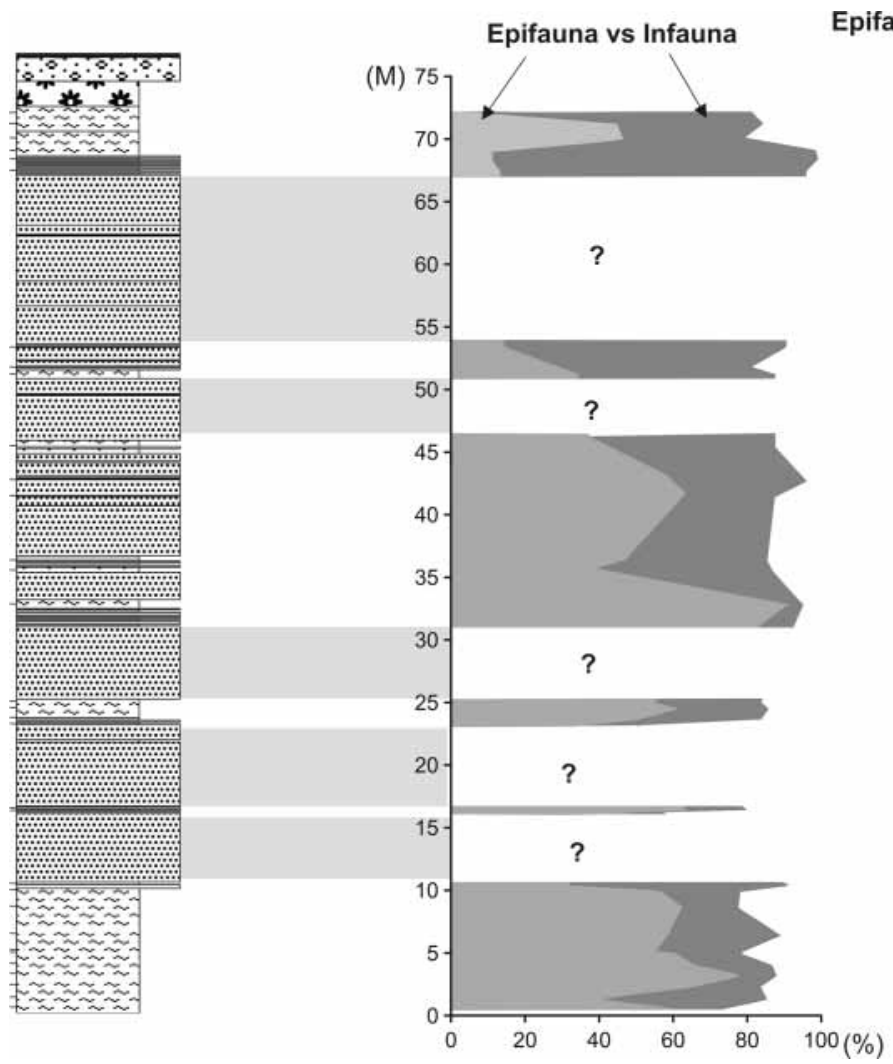

practically absent. In a short interval, at $70.1 \mathrm{~m}$, the small peak in abundance of the oxic indicators, suggests a more oxygenated environment.

\section{Palaeobathymetry}

As is documented by recent studies, the high occurrence of planktonic foraminifera suggests at least an outer neritic environment, with water depths exceeding $150 \mathrm{~m}$ (Hemleben et al., 1989). In modern seas, the percentage of planktonic specimens tends to increase from $<10 \%$ in sheltered coastal water to $>95 \%$ in the open ocean at depths greater than $1000 \mathrm{~m}$ (Gibson, 1989).

Planktonic foraminiferal percentages in the Ag. Giannis section are mostly between $40 \%$ and $70 \%$, commonly $60 \%$, which is consistent with an outer neritic to upper bathyal environment (Murray, 1976).

The overall nature of the benthic assemblages was examined to check the reliability of the aforementioned interpretation. The comparison of the microfossil fauna with habitats of their modern counterparts can be used to estimate the palaeobathymetry.

The $U$. striatissima assemblage, present in the basal part of the section, can be compared with upper bathyal habitats where $U$. peregrina occurred with fewer Cibicidoides spp. and Lenticulina spp. Indeed, in many regions, $U$. peregrina is presently the dominant taxon in the upper bathyal zone (Pflum \& Frerichs, 1976; Schnitker, 1979, 1980; Streeter \& Shackleton, 1979; Qvale \& van Weering, 1985; Gupta \& Srinivasan, 1990), although this

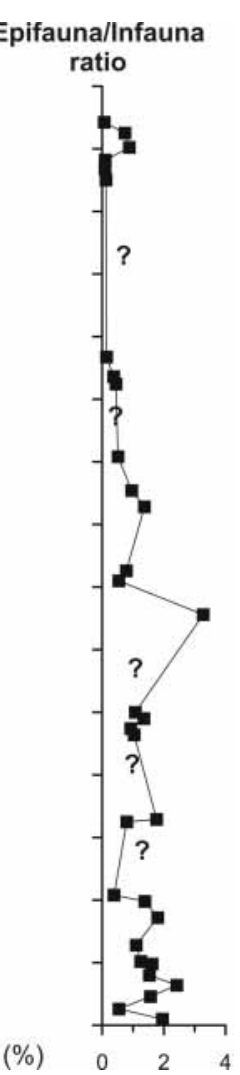

Fig. 9. Distribution patterns of the microhabitat preferences in the succession and distribution of epifauna/infauna ratio. (?) indicates inadequate data due to the existence of thick turbidite beds of Facies 3 (no sampling). See Figure 2 for legend. 


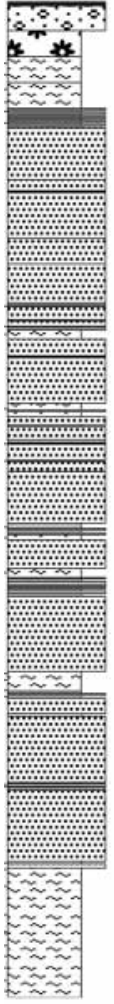

(m)

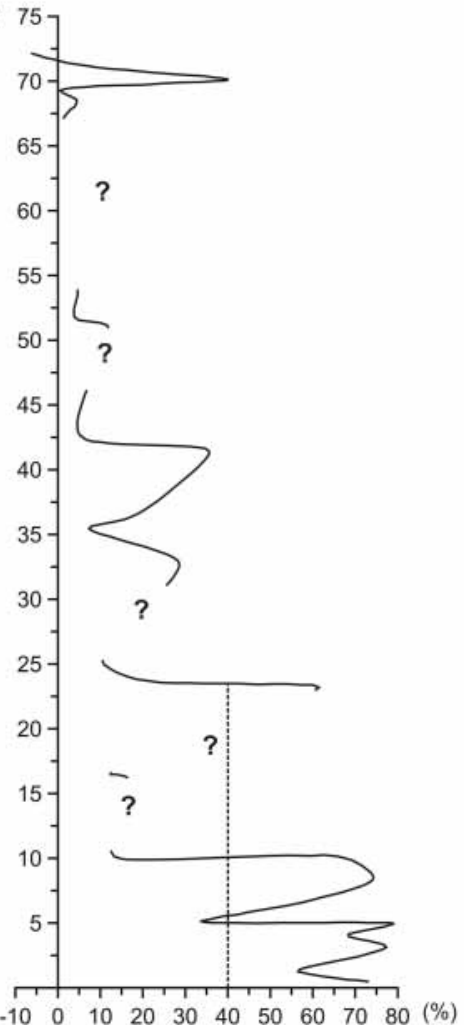

(a)

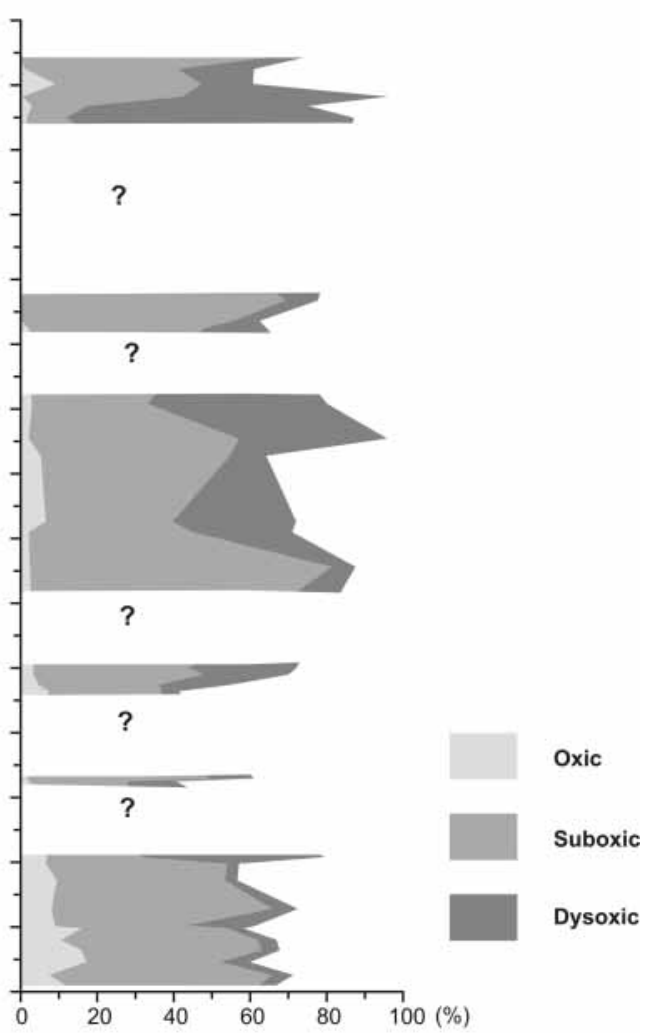

(b)

Fig. 10. (a) Bottom water oxygenation and (b) benthic foraminiferal morphogroups from the Ag. Giannis section. Benthic Foraminifera Oxygen Index (BFOI) values between 39 and 100 correspond to oxygen concentrations $>3 \mathrm{ml} \mathrm{l}^{-1}$. BFOI values from -6 to 39 correspond to oxygen concentrations from $1.5-3 \mathrm{ml}^{-1}$. (?) indicates inadequate data due to the existence of thick turbidite beds of Facies 3 (no sampling). See Figure 2 for legend.

taxon can also be found at abyssal depths (Corliss, 1979). Cibicidoides spp. has an upper depth limit within the middle bathyal in the Gulf of Mexico (Pflum \& Frerichs, 1976). Additionally, C. ungerianus and C. kullenbergi are very abundant deep-water taxa below 100-120 m (Jorissen, 1988; Sgarrella \& Moncharmont Zei, 1993).

From $9.9 \mathrm{~m}$ to $53.37 \mathrm{~m}$, where turbidite deposits prevail, the palaeodepth assignment is difficult due to the possibility of reworking of the specimens. However, the high abundance and good preservation of the low-diversity $V$. complanataGlobobulimina spp. assemblage, in combination with the absence of benthic foraminifera typical of shallow-water environments (e.g. Ammonia beccarii, Elphidium spp.), supports an outer-shelf environment setting.

Finally, in the upper part of the succession, the $B$. alata assemblage indicates deposition in the upper bathyal zone, as also suggested by high abundances of $B$. spathulataldilatata, B. costata and Globocassidulina subglobosa. G. subglobosa is a cosmopolitan species present in a wide bathymetric range and in different water masses (e.g. in the Gulf of Mexico, G. subglobosa occurs in the upper bathyal zone; Pflum \& Frerichs, 1976).

Bulimina costata is recorded to be one of the dominant species representative of upper middle bathyal (610-914 m) biofacies in the Gulf of California (Bandy, 1961). In the Peru-Chile Trench area of the southeastern Pacific, it was found at depths of 150-2000 m, with greatest abundances occurring from $500 \mathrm{~m}$ to
$1500 \mathrm{~m}$ (Ingle et al., 1980). In the Gulf of Mexico, it ranges from $100 \mathrm{~m}$ (Bandy \& Chierici, 1966) to $1676 \mathrm{~m}$ (Pflum \& Frerichs, 1976) but is most common in upper and bathyal zones. In the Sigsbee Plain and Mississippi Fan, it is a common component of the Bolivina-Brizalina facies along the middle and lower slope (Poag, 1981).

\section{DISCUSSION}

The Lower Tortonian deposits of the Ag. Giannis section on Gavdos Island consist of hemipelagic marls interbedded in thick turbidite-like sandy deposits. The increased thickness of litharenitic sands upward in the section reflects strong terrigenous influence (runoff-related turbidites). Therefore, the action of gravity and downslope sediment transport cannot be understated.

In this record, the percentage of planktonic foraminifera over the total assemblages is considerably high. This indicates the presence of an open-marine environment. From the plot of Figure 11, it is evident that percentage values of planktonic foraminifera are fairly consistent, indicating relatively undisturbed sediments. The absence of anomalously low percentage planktonic values indicates either that material transported to the study area arrived in amounts small enough such that values of percentage planktonics were not affected, or that the material was displaced from a location of similar depth characterized by comparable abundances. However, the reduction in benthic 

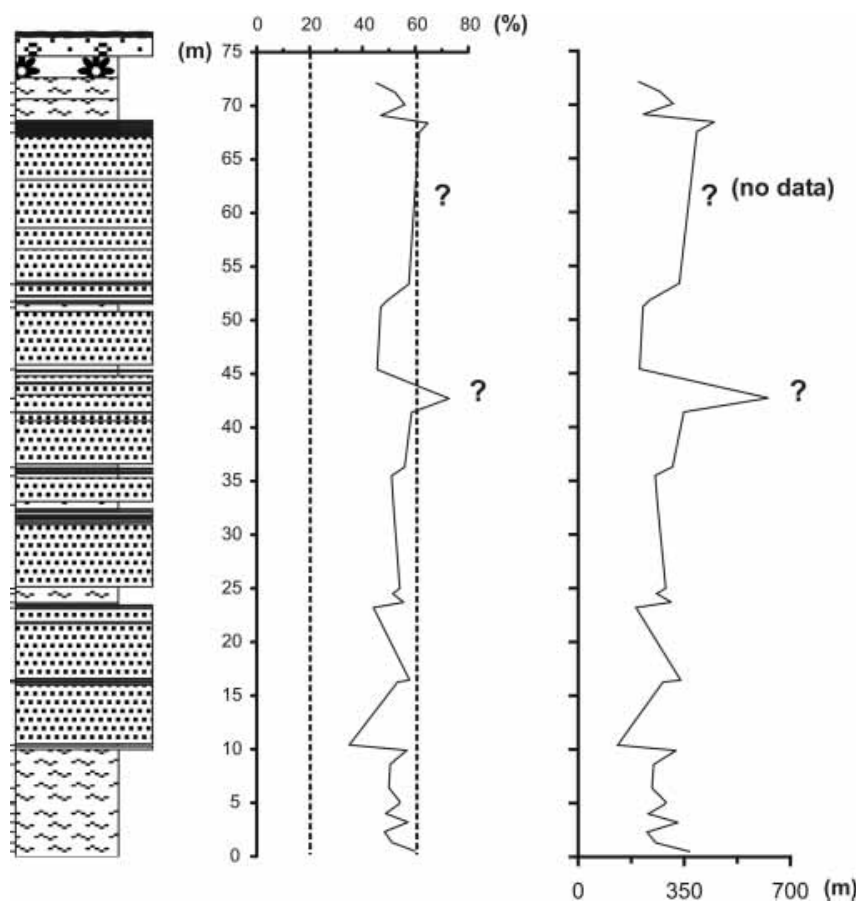

Fig. 11. Plankton/benthos ratio and palaeodepth curve (right) obtained for the studied section. (?) indicates inadequate data due to the existence of thick turbidite beds of Facies 3 (no sampling). See Figure 2 for legend.

foraminifera in the sandy intervals, in combination with the high abundance of the planktonic forms, may be explained by the fact that these layers have been intensively winnowed by bottom currents. Hence, the fine-grained organic detritus and other possible adequate food for benthic foraminifera would have been washed away, thus preventing the small benthic organisms from thriving under these conditions. Nevertheless, this kind of habitat can be favourable for some specialized endobenthic forms ( $V$. complanata-Globobulimina) that take advantage of the food supplied by the strong bottom currents.

\section{Ecosystem evolution}

Major differences in diversity, community structure, feeding and habitat preferences are observed among benthic foraminiferal assemblages across the Ag. Giannis section.

The composition of the pre-turbidite assemblage (first $9.9 \mathrm{~m}$ of the section) is characterized by high diversity and numerous different morphotypes. Sessile suspension feeders, such as Cibicidoides ungerianus and $C$. kullenbergi, occur together with infaunal detritus feeders. All ecological niches were occupied, signifying that the oxygen penetration within the sediment column reached several centimetres (Loubère, 1997) and the redox zone was deep.

The interval from $9.9 \mathrm{~m}$ to $53.37 \mathrm{~m}$ is composed mostly of turbidite-like sediments. The thriving pre-turbiditic assemblage was drastically reduced. Only some sediment-dwelling foraminifera ( $V$. complanata-Globobulimina spp.) could keep pace with burial and survived by utilizing organic matter in the turbidite layer. The microfaunas of this interval are less diversified, with a minimum diversity value at $42.7 \mathrm{~m}$, the percentage values of the epifaunal component show a diminishing trend with small-scale fluctuations and the assemblage is enriched in the infaunal component, indicating a high trophic profile (Zahn et al., 1986). The positive peak of the $V$. complanataGlobobulimina spp. assemblage indicates high bottom productivity due to the increased input of nutrients from the continent (maybe river-induced) (e.g. Van der Zwaan \& den Hartog Jager, 1983).

Above the turbiditic sands, from $53.37 \mathrm{~m}$ to $72.12 \mathrm{~m}$, an oligotypic assemblage (Bolivina alata assemblage) prevails. This 'recolonization' fauna is composed mostly of infaunal forms that are mobile and may take advantage of the small amounts of organic matter which comes to the seafloor during and after the turbidites. Epifaunal benthic forms are represented only by small numbers in the sediments deposited after the turbidites.

It is interesting to note that this low diversity assemblage includes a number of new species, which have not been observed in the abundant and highly-diversified pre-turbidite faunas. Among these are Bolivina alata, Globocassidulina oblonga and Uvigerina gaudrynoides. The increase of Bolivina is linked to poorly oxygenated bottoms and a fine-grained sedimentation setting.

In a short interval, at $70.1 \mathrm{~m}$, the repopulation of the nutrientrich substrate by the low-diversity Bolivina alata assemblage is replaced by species (the shallow infaunal Valvulineria, Uvigerina and the epifaunal Cibicidoides spp.) that are able to occupy a wider range of ecological niches. This repopulation process and the increase in diversity values is suggestive of an improvement in oxygen content in the bottom water, causing a temporary deepening of the redox zone.

The palaeoenvironmental conditions of the Ag. Giannis section reflect the biotic recovery of the benthic ecosystem after a period of intense turbidity activity. The vertical evolution of the benthic foraminiferal assemblages indicates a succession from (a) a pre-disturbance deposit to (b) a disturbance deposit followed by (c) the post-disturbance deposit (sensu Alve, 1999). According to Alve (1999), units (a) and (c) may contain in situ fossils, whereas (b) will be either unfossiliferous (there are 13 barren samples) or contain transported fossils (although they may contain post-disturbance, infaunal taxa which utilize organic matter in the turbidite layers (Rathburn \& Corliss, 1994)).

\section{CONCLUSIONS}

Palaeoecological relationships between benthic foraminifera and environmental factors were analysed in the Lower Tortonian hemipelagic marls and turbidite-like sands of the Ag. Giannis section, Gavdos Island, Greece.

Considerable differences in diversity, community organization, feeding and habitat preferences are detected among benthic foraminiferal assemblages below, across and above the turbiditic episodes.

Prior to the deposition of turbiditic sands, the benthic foraminiferal assemblage (Uvigerina striatissima assemblage) is indicative of a certain environmental stability, as characterized by relatively minor fluctuations in measured faunal parameters. This stability was disrupted by the recurrent deposition of turbiditic sands. Some specialized endobenthic forms, such as Valvulineria complanata and Globobulimina spp., could keep 
pace with high sedimentation in this high-energy regime, taking advantage of the food supplied by the strong bottom currents.

A remarkable pattern that can be interpreted as evidence of faunal recovery characterized the sea floor following the deposition of turbiditic sands. A new assemblage of opportunistic taxa (Bolivina alata assemblage) initiated the process of recolonization. The reduction in the dominance of Bolivina spp. and the reappearance of both infaunal and epifaunal taxa reflects the ongoing recovery of the benthic ecosystem.

\section{ACKNOWLEDGEMENTS}

The authors wish to express their gratitude to Profs S. Iaccarino and S. Spezzaferri for critical comments, support and improvement of an earlier version of the manuscript. Aphroditi Meni, Panagiota Yiannia and Evaggelia Georganta are thanked for helping in the sampling and washing of the micropalaeontological samples. Thanks go to Drs Mike Kaminski, Mike Rogerson and John Gregory for constructive comments on the manuscript. The project is co-funded by the European Social Fund and National Resources - (EPEAEK II) PYTHAGORAS.

\section{Epifaunal taxa}

Anomalinoides spp., Cassidulina laevigata, Cibicides spp., Cibicidoides spp., Dentalina spp., Gavelinopsis lobatulus, Gyroidinoides neosoldanii, Hanzawaia boueana, Heterolepa spp., Lagena sp., Lenticulina spp., Marginulina spp., Marginulinopsis sp., Nodosaria spp., Oridorsalis umbonatus, Orphomorphina sp., Planularia sp., Planulina spp., Plectofrondicularia raricosta, Pyrgo depressa, Quinqueloculina sp., Saracenaria italica, Sigmoilinita tenuis, Siphonina reticulata, Sphaeroidina bulloides, Spiroloculina depressa, Vaginulina legumen, Vaginulinopsis sulcata, Valvulineria complanata.

\section{Infaunal taxa}

Amphicoryna scalaris, Amphicoryna sublineata, Astrononion stelligerum, Bolivina alata, Bolivina dilatata, Bolivina punctata, Bolivina reticulata, Bolivina spathulata, Bolivina tortuosa, Bulimina aculeata, Bulimina costata, Bulimina exilis, Globobulimina sp., Globocassidulina oblongus, Globocassidulina subglobosa, Melonis spp., Nonion sp., Nonionella sp., Pullenia bulloides, Pullenia quinqueloba, Uvigerina gaudrynoides, Uvigerina peregrina, Uvigerina striatissima.

\section{Oxic indicators}

Cibicides lobatulus, Cibicides refulgens, Cibicides sp., Cibicidoides kullenbergi, Cibicidoides pseudoungerianus, Cibicidoides robertsonianus, Cibicidoides ungerianus, Cibicidoides wuellerstorfi, Pyrgo depressa, Quinqueloculina sp.

\section{Suboxic indicators}

Bulimina aculeata, Bulimina costata, Cassidulina carinata, Cassidulina laevigata, Dentalina spp., Globocassidulina oblonga, Globocassidulina subglobosa, Gyroidina soldanii, Gyroidinoides neosoldanii, Hoeglundina elegans, Lenticulina spp., Melonis spp., Nonion spp., Oridorsalis umbonatus, Pullenia spp., Sphaeroidina bulloides, Uvigerina spp., Valvulineria complanata.

\section{Dysoxic indicators}

Bulimina exilis, Bolivina alata, Bolivina dilatata, Bolivina spathulata, Bolivina tortuosa, Chilostomella oolina, Fursenkoina schreibersiana, Globobulimina sp.

\section{Manuscript received 2 June 2005 Manuscript accepted 27 April 2007}

\section{REFERENCES}

AGIP 1982. Foraminiferi Padani, (2nd edn) AGIP S.p.A, San Donato Milanese, Milano.

Alve, E. 1999. Colonisation of new habits by benthic foraminifera: a review. Earth-Science Reviews, 46: 167-185.

Anastasakis, G.C., Dermitzakis, M.D. \& Triantaphyllou, M.V. 1995. Stratigraphic framework of the Gavdos Island Neogene sediments. Newsletters on Stratigraphy, 32: 1-15.

Angelier, J., Lyberis, N., Le Pichon, X., Barrier, E. \& Huchon, P. 1982. The tectonic development of the Hellenic Arc and the Sea of Crete: a synthesis. In: Le Pichon, X., Augoustithis, S.S. \& Mascle, J. (Eds), Geodynamics of the Hellenic Arc and Trench. Tectonophysics, 86: 159-196.

Baas, J.H., Schönfeld, J. \& Zahn, R. 1998. Mid-depth oxygen drawdown during Heinrich Events: Evidence from benthic foraminiferal community structure, trace fossil tiering, and benthic $\delta 13 \mathrm{C}$ at the Portuguese Margin. Marine Geology, 152: 25-55.

Balance, P.F. 1988. The Huriwai braidplain delta of New Zealand: a late Jurassic, coarse-grained, volcanic-fed depositional system in a Gondwana forearc basin. In: Nemec, W. \& Steel, R.J. (Eds), Fan Deltas: Sedimentology and Tectonic Settings. Blackie \& Son Ltd, London, 430-444.

Bandy, O.L. 1961. Distribution of foraminifera, radiolaria and diatoms in sediments of the Gulf of California. Micropalaeontology, 7: 1-26.

Bandy, O.L. \& Chierici, M.A. 1966. Depth temperature evaluation of selected Californian and Mediterranean bathyal foraminifera. Marine Geology, 4: 259-271.

Barmawidjaja, D.M., Jorissen, F.J., Puskaric, S. \& Van der Zwaan, G.J. 1992. Microhabitat selection of benthic foraminifera in the northern Adriatic Sea. Journal of Foraminiferal Research, 22: 297-317.

Bellanca, A., Sgarrella, F., Neri, R., Russo, B., Sprovieri, M., Bonaduce, G. \& Rocca, D. 2002. Evolution of the Mediterranean Basin during the Late Langhian-Early Serravallian: an integrated palaeoceanographic approach. In: Iaccarino, S. (Ed.), Integrated Stratigraphy and Palaeoceanography of the Mediterranean Middle Miocene. Rivista Italiana di Palaeontologia e Stratigrafia, 108: 223-239.

Betzler, C., Brachert, T.C. \& Nebelsick, J. 1997. The warm-temperate carbonate province - a review of the facies, zonations and delimitations. Courier Forschungsinstitut Senckenberg, 201: 83-99.

Bizon, G. \& Bizon, J.J. 1984. Ecologie des foraminifers en Mediterranee nord-occidentale. Les foraminferes des sediments profound. In: Ecologie des microorganisms en Mediterranee occidentale. "Ecomed". Petrole et Techniques, 301: 104-139.

Blanc-Vernet, L., Clairfond, P. \& Orsolini, P. 1979. La mer Pelagienne. Les foraminifers. Géologie Méditerranéenne, 6: 171-209.

Blow, W.H. 1969. Late middle Eocene to Recent planktonic foraminiferal biostratigraphy. In: Bronnimann, P. \& Renz, H.H. (Eds), Proceedings of First Planktonic Conference. E. J. Brill, Leiden, $199-422$.

Borsetti, A.M., Iaccarino, S., Jorissen, F.J., Poignant, A., Sztrakos, K., van der Zwaan, G.J. \& Verhallen, P.J.J.M. 1986. The Neogene Development of Uvigerina in the Mediterranean. Utrecht Micropalaeontological Bulletins, 35: 183-235.

Bouma, A.H., Normark, W.R. \& Barnes, N.E. (Eds), 1985. Submarine Fans and Related Turbidite Systems. Springer-Verlag, New York, $1-351$.

Brachert, T.C., Forst, M.H., Pais, J.J., Legoinha, P. \& Reijmer, J.J.G. 2003. Lowstand carbonates, highstand sandstones. Sedimentary Geology, 155: 1-12.

Cimerman, F. \& Langer, M. 1991. Mediterranean Foraminifera. Slovenska Akademija Znanosti in Umetnosti. Academia Scientiarum 
Artium Slovenica, Ljubliana, Classis IV. Historia Naturale, 30: 1-118.

Colmenero, J.R., Agueda, J.A., Fernandez, L.P., Salvador, C.I., Bahamonde, J.R. \& Barba, P. 1988. Fan-delta systems related to the Carboniferous evolution of the Cantabrian Zone, northwestern Spain. In: Nemec, W. \& Steel, R.J. (Eds), Fan Deltas: Sedimentology and Tectonic Settings. Blackie \& Son Ltd, London, 267-285.

Corliss, B.H. 1979. Recent deep-sea benthonic foraminiferal distributions in the southeast Indian Ocean: inferred bottom-water routes and ecological implications. Marine Geology, 31: 115-138.

Corliss, B.H. 1991. Morphology and microhabitat preferences of benthic foraminifera from the Northwest Atlantic Ocean. Marine Micropalaeontology, 17: 195-236.

Corliss, B.H. \& Emerson, S. 1990. Distribution of Rose Bengal stained deep-sea benthic foraminifera from the Nova Scotia continental margin and Gulf of Maine. Deep-Sea Research, 37: 381-400.

Dabrio, C.J. \& Polo, M.D. 1988. Late Neogene fan deltas and associated coral reefs in the Almanzora Basin, Almeria Province, southeastern Spain. In: Nemec, W. \& Steel, R.J. (Eds), Fan Deltas: Sedimentology and Tectonic Settings. Blackie \& Son Ltd, London, 354-367.

Drinia, H., Antonarakou, A., Tsaparas, N. \& Kontakiotis, G. 2004a. Palaeoecological aspects preceding the Messinian Salinity Crisis: A case from Gavdos Island. Environment and Identity in the Mediterranean: The Messinian Salinity Crisis Revisited. 4th International Congress, 25-29 July, Corte, Abstracts: 33.

Drinia, H., Antonarakou, A., Tsaparas, N., Dermitzakis, M.D. \& Doukas, C. 2004b. Foraminiferal sequence eco-biostratigraphy of the Middle-early Late Miocene Potamos Section from Gavdos Island, Greece. Courier Forschungsinstitut Senckenberg, 249: 29-43.

Esteban, M. 1979. Significance of the upper Miocene coral reefs of the western Mediterranean. Palaeogeography, Palaeoclimatology, Palaeoecology, 29: 169-188.

Foresi, L.M., Iaccarino, S., Mazzei, R. \& Salvatorini, G. 1998. New data on middle to late Miocene calcareous plankton biostratigraphy in the Mediterranean area. Rivista Italiana di Palaeontologia e Stratigrafia, 104: 95-114.

Foresi, L.M., Bonomo, S., Caruso, A., et al. 2002a. High resolution calcareous plankton biostratigraphy of the Serravallian succession of the Tremiti Islands (Adriatic Sea, Italy). In: Iaccarino, S. (Eds), Integrated Stratigraphy and Palaeoceanography of the Mediterranean Middle Miocene. Rivista Italiana di Palaeontologia e Stratigrafia, 108: 257-273.

Foresi, L.M., Iaccarino, S.M. \& Salvatorini, G. 2002b. Neogloboquadrina atlantica praeantlantica, new subspecies from Late Middle Miocene. In: Iaccarino, S. (Ed.), Integrated Stratigraphy and Palaeoceanography of the Mediterranean Middle Miocene. Rivista Italiana di Palaeontologia e Stratigrafia, 108: 325-336.

Fortuin, A.R. 1977. Stratigraphy and sedimentary history of the Neogene deposits in the Ierapetra region, Eastern Crete. GUA Paper of Geology, Series 1, 8: 1-164.

Fortuin, A.R. 1978. Late Cenozoic history of eastern Crete and implications for the geology and geodynamics of the southern Aegean Sea. Geologie en Mijnbouw, 57: 451-464.

Gibson, T.G. 1989. Planktonic benthonic foraminiferal ratios: modern patterns and Tertiary applicability. Marine Micropalaeontology, 15: $29-52$.

Gradstein, F.M., Ogg, J.G. \& Smith, A.G. 2004. A Geologic Time Scale 2004. Cambridge University Press, Cambridge, 500pp.

Gupta, A.K. \& Srinivasan, M.S. 1990. Response of northern Indian Ocean deep-sea benthic foraminifera to global climates during Pliocene-Pleistocene. Marine Micropalaeontology, 16: 77-91.

Hammer, O., Harper, D.A.T. \& Ryan, P.D. 2001. PASTPalaeontological Statistics software package for education and data analysis. Palaeontologica Electronica, 4: 9pp http:// palaeo-electronica.org/2001_1/past/issue.

Hemleben, Ch., Spindler, M. \& Anderson, O.R. 1989. Modern Planktonic Foraminifera. Springer-Verlag, New York, 363pp.

Hilgen, F.J. 1991. Extension of the astronomically calibrated (polarity) time scale to the Miocene/Pliocene boundary. Earth and Planetary Science Letters, 107: 349-368.

Hilgen, F.J., Krijgsman, W., Langereis, C.G., Lourens, L.J., Santarelli, A. \& Zachariasse, W.J. 1995. Extending the astronomical (polarity) time scale into the Miocene. Earth and Planetary Science Letters, 136: $495-510$.

Hilgen, F.J., Krijgsman, W., Raffi, I., Turco, E. \& Zachariasse, W.J. 2000. Integrated stratigraphy and astronomical calibration of the Serravallian/Tortonian boundary Section at Monte Gibliscemi (Sicily, Italy). Marine Micropalaeontology, 38: 181-211.

Hilgen, F.J., Abdul Aziz, H., Krijgsman, W., Raffi, I. \& Turco, E. 2003. Integrated stratigraphy and astronomical tuning of the Serravallian and lower Tortonian at Monte dei Corvi (Middle-Upper Miocene, northern Italy). Palaeogeography, Palaeoclimatology, Palaeoecology, 199: 229-264.

Ingle, J.C. Jr, Keller, G. \& Kolpack, R.L. 1980. Benthic foraminiferal biofacies, sediments and water masses of the southern Peru-Chile Trench area, southeastern Pacific Ocean. Micropalaeontology, 26: $113-150$.

James, N.P., Bone, Y., Collins, L.B. \& Kyser, T.K. 2001. Surficial sediments of the Great Australian Bight: facies dynamics and oceanography on a vast cool-water carbonate shelf. Journal of Sedimentary Research, 71: 549-567.

Jonkers, H.A. 1984. Pliocene benthonic foraminifera from homogeneous and laminated marls on Crete. Utrecht Micropalaeontological Bulletins, 31: 1-179.

Jorissen, F.J. 1987. The distribution of benthic foraminifera in the Adriatic Sea. Marine Micropalaeontology, 12: 21-48.

Jorissen, F.J. 1988. Benthic foraminifera from the Adriatic Sea: principles of phenotypic variation. Utrecht Micropalaeontological Bulletins, 37: $1-174$.

Jorissen, F.J. 1999. Benthic foraminiferal successions across Late Quaternary Mediterranean sapropels. Marine Geology, 153: 91-101.

Jorissen, F.J. \& Wittling, I. 1999. Ecological evidence from live-dead comparisons of benthic foraminiferal faunas off Cape Blanc (Northwest Africa). Palaeogeography, Palaeoclimatology, Palaeoecology, 149: $151-170$.

Jorissen, F.J., Barmawidjaja, D.M., Puskaric, S. \& van der Zwaan, G.J. 1992. Vertical distribution of benthic foraminifera in the northern Adriatic Sea: the relation with the organic flux. Marine Micropalaeontology, 19: 131-146.

Kaiho, K. 1991. Global changes of Palaeogene aerobic/anaerobic benthic foraminifera and deep-sea circulation. Palaeogeography, Palaeoclimatology, Palaeoecology, 83: 65-85.

Kaiho, K. 1994. Benthic foraminiferal dissolved oxygen index and dissolved oxygen levels in the modern ocean. Geology, 22: 719-722.

Katz, M.E. \& Thunnell, R.C. 1984. Benthic foraminiferal biofacies associated with Middle Miocene to Early Pliocene oxygen-deficient conditions in the eastern Mediterranean. Journal of Foraminiferal Research, 14: 187-202.

Korringa, P. 1952. Recent advances in oyster biology. Quarterly Review of Biology, 27: 339-365.

Kouwenhoven, T.J., Hilgen, F.J. \& van der Zwaan, G.J. 2003. Late Tortonian-early Messinian stepwise disruption of the MediterraneanAtlantic connections: constraints from benthic foraminiferal and geochemical data. Palaeogeography, Palaeoclimatology, Palaeoecology, 198: 303-319.

Kovach, W. 1987. Multivariate methods of analyzing palaeoecological data. In: Dimichele, W. \& Wing, S.H. (Eds), Methods and Applications of Plant Paleoecology, Palaeontological Society Special Publications, 3: $72-104$.

Kovach, W. 1989. Comparisons of multivariate analytical techniques for use in Pre-Quaternary plant palaeoecology. Review of Palaeobotany and Palynology, 60: 255-282.

Krijgsman, W., Hilgen, F.J., Langereis, C.G., Lourens, L.J., Santarelli, A. \& Zachariasse, W.J. 1995. Late Miocene magnetostratigraphy, biostratigraphy and cyclostratigraphy from the Mediterranean. Earth and Planetary Science Letters, 136: 475-494.

Krijgsman, W., Fortuin, A.R., Hilgen, F.J., Sierro, F.J. \& Vai, G.B. 1998. Astronomically forced cyclicity in the Messinian evaporates. 15th International Sedimentological Congress, April 12-17, Alicante, Abstracts: 480.

Krijgsman, W., Langereis, C.G., Zachariasse, W.J., et al. 1999. Late Neogene evolution of the Taza-Guercif Basin (Rifian Corridor, Morocco) and implications for the Messinian salinity crisis. Marine Geology, 153: 147-160. 
Loeblich, A.R. \& Tappan, H. 1988. Foraminiferal Genera and their Classification. 2 vols. Van Nostrand \& Reinhold, New York, 970pp.

Loubère, P. 1997. Benthic foraminiferal assemblage formation, organic carbon flux and oxygen concentrations on the outer continental shelf and slope. Journal of Foraminiferal Research, 27: 93-100.

Marzo, M. \& Anadon, P. 1988. Anatomy of a conglomeratic fan-delta complex: the Eocene Montserrat Conglomerate, Ebro Basin, northeastern Spain. In: Nemec, W. \& Steel, R.J. (Eds), Fan Deltas: Sedimentology and Tectonic Settings. Blackie \& Son Ltd, London, 318-340.

McKenzie, D.P. 1978. Active tectonics of the Alpine Himalayan belt: the Aegean Sea and surrounding regions. Geophysical Journal of the Royal Astronomical Society, 58: 217-254.

Meulenkamp, J.E., Wortel, M.J.R., van Wamel, W.A., Spakman, W. \& Hoogerduyn Strating, E. 1988. On the Hellenic subduction zone and the geodynamic evolution of Crete since the late Middle Miocene. Tectonophysics, 146: 1-13.

Murray, J.W. 1976. A method of determining proximity of marginal seas to an ocean. Marine Geology, 22: 103-119.

Murray, J.W. 1991. Ecology and palaeoecology of Benthonic Foraminifera. Longman Scientific \& Technical, London, 274pp.

Peters, J.M. \& Troelstra, S.R. 1984. Early Pliocene sedimentation in the Cretan region: implications for the timing and amount of vertical motion along the South Hellenic Arc (Eastern Mediterranean). Marine Geology, 56: 335-344.

Pflum, C.E. \& Frerichs, W.D. 1976. Gulf of Mexico deep-water foraminifera. Cushman Foundation of Foraminiferal Research, Special Publications, 14: 1-125.

Pirrie, D. 1989. Shallow marine sedimentation within an active margin basin, James Ross Island, Antarctica. Sedimentary Geology, 63: 61-82.

Poag, C.W. 1981. Ecologic Atlas of Benthic Foraminifera of the Gulf of Mexico. Hutchinson Ross Publishing Company, Stroudsburg PA, $174 \mathrm{pp}$.

Qvale, G. \& van Weering, T.C.E. 1985. Relationship of surface sediments and benthic foraminiferal distribution patterns in the Norwegian Channel (Northern North Sea). Marine Micropalaeontology, 9: 469-488.

Rathburn, A.E. \& Corliss, B.H. 1994. The ecology of living (stained) deep-sea benthic foraminifera from the Sulu Sea. Paleoceanography, 9: $87-150$.

Rosenthal, L.R.P. \& Walker, R.G. 1987. Lateral and vertical facies sequences in the Upper Cretaceous Chungo member, Wapiabi formation, southern Alberta. Canadian Journal of Earth Sciences, 24: 771-783.

Schnitker, D. 1979. The deep waters of the western North Atlantic during the past 24,000 years, and the re-initiation of the Western Boundary Undercurrent. Marine Micropalaeontology, 4: 265-280.

Schnitker, D. 1980. North Atlantic oceanography as possible cause of Antarctic glaciation and eutrophication. Nature, 284: 615-616.

Seidel, E. \& Okrusch, M. 1978. Regional distribution of critical metamorphic minerals in Crete. In: Closs, H., Roeder, H.D. \& Schmidt, K.E. (Eds), Alps, Apennines, Hellenides. Schweizerbart, Stuttgart, 448-452.

Sgarrella, F. \& Moncharmont Zei, M. 1993. Benthic foraminifera of the Gulf of Naples (Italy): systematics and autecology. Bollettino della Societa Palaeontologica Italiana, 32: 145-264.

Shepard, F.P. 1963. Submarine Geology, (2nd edn) Harper \& Row, New York.

Sjoerdsma, P.G. \& van der Zwaan, G.J. 1992. Simulating the effect of changing organic flux and oxygen content on the distribution of benthic foraminifera. Marine Micropalaeontology, 19: 163-180.

Stefanelli, S. 2004. Cyclic changes in oxygenation based on foraminiferal microhabitats: Early-Middle Pleistocene, Lucania Basin (southern
Italy). Journal of Micropalaeontology, 23: 81-95.

Stow, D.A.V. 1986. Deep clastic seas. In: Reading, H.G. (Ed.), Sedimentary Environments and Facies, (2nd edn) Blackwell Scientific, Oxford, 399-444.

Stow, D.A.V. \& Piper, D.J.W. 1984. Deep water fine-grained sediments: Facies models. In: Stow, D.A.V. \& Piper, D.J.W. (Eds), Fine Grained Sediments: Deep Water Processes and Facies. Geological Society, London, Special Publications, 15: 611-646.

Streeter, S.S. \& Shackleton, N.J. 1979. Palaeocirculation on the deep North Atlantic: 150,000 yr. record of benthic foraminifera and oxygen-18. Science, 203: 168-170.

Triantaphyllou, M.V., Tsaparas, N., Stamatakis, M. \& Dermitzakis, M.D. 1999. Calcareous nannofossil biostratigraphy and petrological analysis of the pre-evaporitic diatomaceous sediments from Gavdos Island, southern Greece. Neues Jahrbuch fur Geologie und Palaontologie-Monatshefte, 3: 161-178.

Van Leewen, R.J.W. 1986. The distribution of Uvigerina in the Late Quaternary sediments of the deep eastern South Atlantic. Utrecht Micropalaeontological Bulletins, 35: 47-66.

Van de Poel, H.M. 1992. Foraminiferal biostratigraphy and palaeoenvironments of the Miocene-Pliocene Carboneras-Nijar Basin (SE Spain). Scripta Geologica, 102: 1-32.

Van der Zwaan, G.J. 1982. Palaeoecology of Late Miocene foraminifera. Utrecht Micropalaeontological Bulletins, 25: 1-201.

Van der Zwaan, G.J. 1983. Quantitative analyses and the reconstruction of benthic foraminifera communities. Utrecht Micropalaeontological Bulletins, 30: 49-69.

Van der Zwaan, G.J. \& Gufjonsson, L. 1986. Middle Miocene-Pliocene stable isotope stratigraphy and palaeoceanography of the Mediterranean. Marine Micropalaeontology, 10: 71-90.

Van der Zwaan, G.J. \& Jorissen, F.J. 1991. Biofacial patterns in river-induced shelf anoxia. In: Tyson, R.V. \& Pearson, T.H. (Eds), Modern and Ancient Continental Shelf Anoxia. Geological Society, London, Special Publications, 58: 65-82.

Van der Zwaan, G.J. \& den Hartog Jager, D. 1983. Palaeoecology of Late Miocene Sicilian benthic foraminifera. Proceedings of the Koninklijke Nederlandse Akademie van Wetenschappen, Series B, 86: 211-223.

Venec-Peyre, M.T. 1984. Etude de la distribution des foraminiferes vivant dans la baie de Banyuls-sur-Mer. In: Bizon, J.J. \& Burollet, P.F. (Eds), Ecologie des microorganismes en Méditerranée occidentale 'ECOMED'. Association Francaise des Techniciens du Petrole, 60-80.

Vicente, E. 1970. Etude geologique de l'ile de Gavdos (Grece), la plus meridional de l'Europe. Bulletin de la Societé Géologique de France, 7: 481-495.

Ward, J.H. 1963. Hierarchical grouping to optimize an objective function. Journal of the American Statistical Association, 58: 236-244.

Wells, H.W. 1961. The fauna of oyster reefs with special reference to the salinity factor. Ecological Monographs, 31: 239-266.

Wonders, A.A.H. \& van der Zwaan, G.J. 1979. The smaller benthic foraminifera in section Potamidha 1. Utrecht Micropalaeontological Bulletins, 21: 27-58.

Wright, R. 1978. Neogene palaeobathymetry of the Mediterranean based on benthic foraminifers from DSDP Leg 42A. In: Hsü, K.J., Montadert, L. et al. (Eds). Initial Reports of the Deep Sea Drilling Project, 42: 837-847.

Zachariasse, W.J. 1992. Neogene planktonic foraminifers from Sites 761 and 762 off northwest Australia. Proceedings of the Ocean Drilling Program, Scientific Results, 122: 665-675.

Zahn, R., Winn, K. \& Sarnthein, M. 1986. Benthic foraminiferal $\delta^{13} \mathrm{C}$ and accumulation rates of organic carbon (Uvigerina peregrina group and Cibicidoides wuellerstorfi). Palaeoceanography, 1: 27-42. 